\title{
71. 非相称性フィルム利用による特性曲線選択システムの試み
}

Studies of characteristic curve selection system by using of asymmetric film

\author{
大阪大学医学部附属病院 中央放射線部 \\ ○祐延良治 高橋秀彰 前田大助 佐藤和彦 森 嘉信 \\ Yoshiharu Sukenobu Hideaki Takahashi Daisuke Maeda Kazuhiko Sato Yoshinobu Mori
}

【目的】非相称性フィルムは、増感紙を選ぶことにより、利用者の意図した特性曲線を作ること が可能である。我々はコンピュータを使って、画面上で特性曲線の形を指定することにより、最 適な増感紙の組合せが自動的に提示されるような増感紙選択支援システムの作成を試みた。 【使用機器】フィルム:Kodak InSight, TML-1, Dupont CRONEX 10 増感紙: Kodak INSIGHT HC, Lanex FINE,Lanex MEDIUM,Lanex REGULAR,Lanex FAST , Fuji HR-3,HR-4, Dupont HI-PLUS 濃度 計: Konica PDM-5B(改良型), Fuji MODEL 301RS 自動現像機: Kodak M8-RA 現像定着液: Kodak RP コンピュータ:NEC PC-9801RA(N88日本語BASIC)

【方法】(1)InSightフィルムに組合せる増感紙をフロント㑡とバック側を同一種類にした場合と、 異なる種類にした場合について、それぞれ、距離法を使って階段露光した試料を作成する。（2） 同様に、InSightフイルムの片面に増感紙、反対面に遮光紙をセットした組合せを作り、距離法を 使って階段露光した試料を作成する。(3)上記試料の片面の一部を漂白剂で除去し、片面抢よび 両面の濃度を濃度計を使って測定し、コンピュータへ入力する。(4)この片面の濃度データを使 ってフロント側、バック側に各増感紙を使用した全組合せの特性曲線をコンピュータを用いて作 成する(Fig.1)。(5)利用者が理想とする基準特性曲線を、既成の特性曲線に数值で補正する形で入 力し、作成する。6.コンピュータプログラムにより、基準特性曲線に対し、各増感紙組合せに よる特性曲線が重なるようにX線強度方向にシフトさせ、それぞれ最も誤差面積が小さくなる点 をさがす。その点の誤差面積、シフト量（感度差）を算出する。7. 各増感紙組合せの誤差面積 のうち、最小のものが基準特性曲線に最も近い増感紙の組合せであると判断し、画面上に表示す る。

【結果】フィルム両面に増感紙をセットし、露光した試料の片面の濃度を測定し、コンピュータ 上で加算した特性曲線は、雨面の濃度を一度に測定して作成した特性曲線と非常に良く一致し、 加法性が確認された。また、フロント側とバック㑡を同一種類にした試料の濃度データから作成 したフロント側とバック側が異なる組合せの特性曲線は、実際に組合せて作成した特性曲線とも 良く一致した(Fig.2)。これらょり、既知の増感紙組合せデータより未知の組合せの特性曲線をシ ミュレートできることが確認された。コンピュータにより提示される誤差面積の最も少ない組合 せは、選択できる增感紙に限りがあるため、基準特性曲線と必ずしも同一形状とはならないが、 最も近い組合せであることが確認できた(Fig.3)。

【考察】(1)増感紙の組合せを全部撮影することなく、一部の組合せデータから全組合せの特性曲 線をシミュレート可能である。(2)利用者の求めたい基準曲線に近い特性の得られる増感紙の組合 せを少ない労力で知ることができる。(3)利用者の求める画像の特性は、特性曲線のみで決るわけ ではないので、このシステムのみでフィルム増感紙の組合せを決定することはできないが、選択 支援として十分役に立つと思われる。

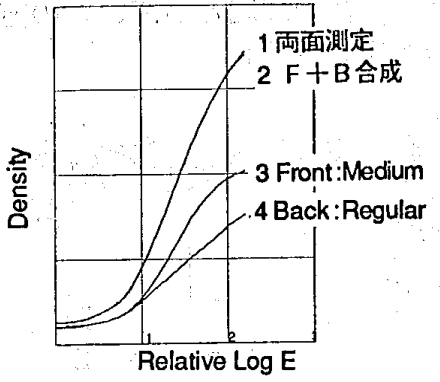

Fig. 1 㴗度加法性の確詻

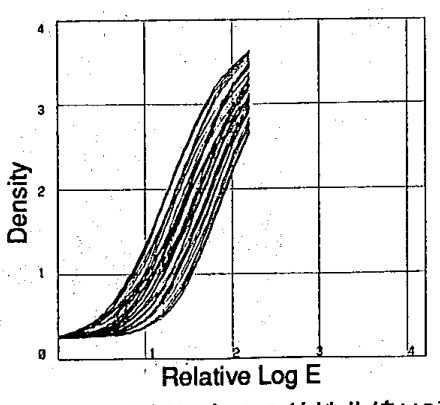

Fig.2 各增感紙組合せの特性曲線(49種)

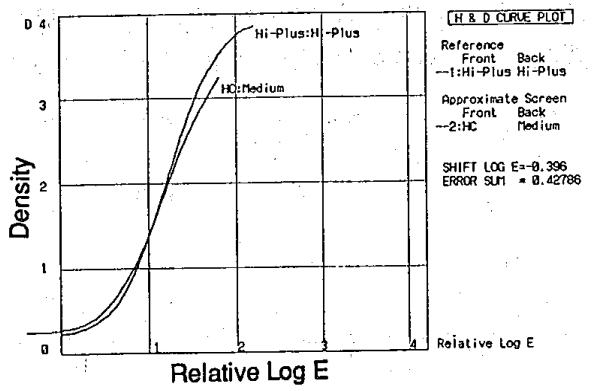

Fig.3 基準曲線と自動選出の組合せ 